\title{
Proposals on establishing a methodology for the systematic analysis of energy coal mixtures in judicial practice
}

\author{
Csaba Lorinț, Eugen Traistă, and Adrian Florea* \\ University of Petrosani, Faculty of Mining Engineering, Department of Environmental Engineering \\ and Geology, Universitatii street, No. 20, 332006, Romania
}

\begin{abstract}
There are several situations in which it is necessary to clarify the types of coal that enter into the composition of mixtures: technical expertise and/or establishing the nature of some coal wastes, often from old stockpiles, in order to eliminate them. The proposed method is based on the identification and description of those mineralogical-petrographic and physico-chemical properties whose pursuit can lead to a diagnosis in differentiation of coal types. Systematic analysis involves in the first stage the identification of the different types of coal present in the sample by mineralogical analysis. From the sample subjected to mineralogical analysis, granules are extracted from the different types of coal present in the sample and the characteristics defining them are determined: moisture and hygroscopic moisture content, volatile matter content, fixed carbon content, agglutination characteristics, etc. Further, the characteristics of the mixtures are determined on another part of the sample and their structure is determined by algebraic methods.
\end{abstract}

\section{Introduction}

The necessity of differentiating the types of coal from mixtures is mainly encountered in two situations, namely: in the case of thefts and/or in the case of an uncertain statute of some coal stockpiles and/or energy mixtures. Both situations are common, especially in former mining areas that are restructuring or in places where different branches of industry (siderurgical, chemical and others) called for the presence of coal stockpiles or energy mixtures or their circulation by different means (industrial platforms, ports, stations and others). The juridical implications are due, on one side, to the necessity of clarifying the often uncertain statute of such stockpiles, abandoned in many cases - in these situations, the ambiental rehabilitation of those terrains is needed, due to ecological reasons or due to the fact that the plots of land have a new owner and/or purpose. Other juridical implications occur in the case of coal and/or energy mixtures theft, situations which are common especially in former mining areas or in restructuring mining areas, where economic and social poverty dominate the daily landscape. An example is found in some of the mining

Corresponding author: adrianflorea@upet.ro 
towns in the Jiu Valley, where the restructuring of the mining industry, doubled by the authorities' inability to design sustainable economic measures, brings a large part of the population to the threshold of poverty or even the failure of some administrations. In a general climate of passivity and even complicity of the authorities, the media is the only entity that sporadically refers to this subject - albeit timidly. Here are e few such examples: Furturile de cărbune din Valea Jiului s-au inmulţit simţitor (Coal theft in the Jiu Valley has sensibly risen), 2nd of December 2009, source: Realitatea TV [7], Nouă bărbați cu vârste intre 20 de ani și 50 de ani au fost reținuți de polițiștii TF în urma unei anchete care vizează furturile de cărbune din vagoanele de marfă din Stațiile CF Iscroni-Aninoasa şi din incinta E.M. Livezeni (Nine men aged 20 to 50 were detained by the police following an investigation regarding coal theft from the box cars in railway stations Iscroni - Aninoasa and from the enclosure of mining plant Livezeni), 29th of March 2018, Source: Ziarul Hunedoreanului [8], Romania's bankrupt town, 1st of September 2013, Source: Reuters [9].

An evil that's been propagated through decades, coal theft can offer a living at the limit of subsistence for numerous poor families, but it also seems to be a source of wealth of some so-called "entrepreneurs", reason for which the real figures regarding the prejudice are well-kept secrets. The few figures that can be seen through this complex and complicated situation show that, only in the case of the hard coal in the Jiu Valley, hundreds of tons are gone missing annually. The coal disappears directly from silos or, most often, from the transportation routes from the mining plants to steam power plants. Although completely justified when considering the scope of the prejudice, legal measures prove to be extremely hard to enforce - measures like the identification and apprehension of the thieves, continuing with the identification of the type and source of coal - and thus, implicitly, the value of the prejudice is impossible to be determined. There are numerous incidents and the real figures are hard to obtain but we can consider losses of over 720 reported tons at the beginning of 2018 and around 700.000 lei prejudice for last year. But the real quantities are estimated to be much higher, which often leads to media titles like: Nu produc cât se furã. Productia de cãrbune din Valea Jiului este la un minim istoric, însã afacerile cu huilã încã merg mai departe (They can't extract enough for the thieves. Coal production in the Jiu Valley is at an historical minimum, but business with hardcoal keeps going), 29th of august 2019, Source: Cronica Văii Jiului [10].

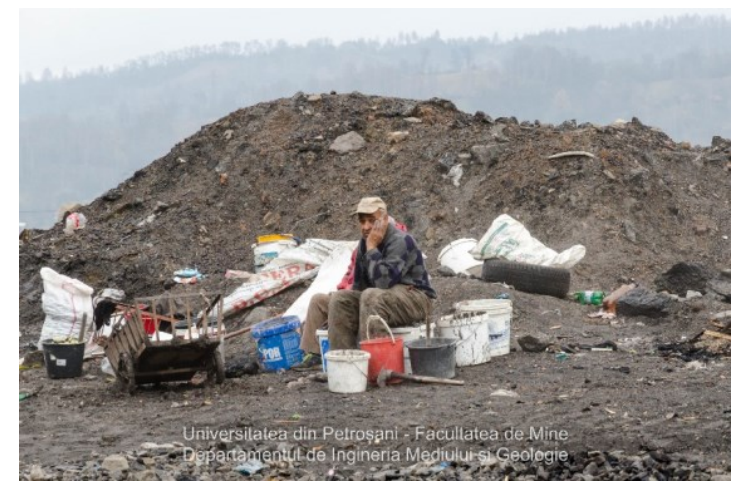

Fig. 1. Clandestine coal picker working in the enclosure of some mining plants or on the sterile dumps

In Romania, known hard coal deposits are only in the Middle Carpathians, in the Carpathian orogen, both in the Danubian and Getic Domains, but also in the post-tectonic intra-mountainous basins [1], [5], [6]. Based on some data presented in 2013-2014 studies, the total reserves of hard coal in Jiu Valley basin amounted to 1,057.550 million tonnes, 94.189 million tons of them being considered available at that moment. The same studies 
showed a total production amounting to 1.5 million tons in 2013. All of these, related to the energy balance from 2013, for all proven reserves in the active mining perimeters, could sustain the coal consumption for the next 60 years. Present data show a real decline for mining production in the Jiu Valley basin [2], [3].

\section{Working methodology}

In the situations described above, in the case of coal thefts, the mixtures consisted of coal belonging to the same type/ore deposit stolen from different mining plants or from coal stolen from different points of the production-transportation-storage flux. In what regards the identification of coal from abandoned storehouses, it can be contaminated with other materials, rocks, soil, construction materials etc. The proposed method is based on the identification and the description of those mineralogical-petrographic and physico-chemical properties of the coals. The method can lead to a diagnosis for a certain differentiation of the types of coal that compose certain mixtures or energy mixtures. In a first phase, the systematic analysis consists of identifying the different types of coal that are present in the sample, using mineralogical-petrographic analysis. From the sample subjected to mineralogical analysis, we extract granules from different types of coal that are present in the sample and we determine the characteristics that define them: moisture and hygroscopic moisture content, volatile matter content, fixed carbon content, agglutination characteristics, etc. Further, the characteristics of the mixtures are determined on another part of the sample and their structure is determined by algebraic methods.

\section{Characteristics of energy coals that allow their differentiation depending on their origin}

In order to realize this, it was necessary to undertake some tests that would determine certain characteristics of the coal, that allow its differentiation depending on its type, and, implicitly, depending on the area of origin. The considered characteristics are: Volatile matter content, Agglutination characteristics, Humidity, Mineralogical characteristics. Volatile matter content represents the fraction of the coal 's mass that is liberated from the coal when heated at 950 degrees Celsius, in the absence of air. Volatile matter content decreases in the following order: peat coal, lignite brown coal, hard coal, anthracite.

Table 1. The volatile matter of different types of coal

\begin{tabular}{|l|l|}
\hline \multicolumn{1}{|c|}{ Coal types } & Volatile matter content [\%] \\
\hline Peat coal & 60 \\
\hline Lignite & 60 \\
\hline Dull brown coal & $50-60$ \\
\hline Glossy brown coal & $50-60$ \\
\hline Flaming hard coal & $40-50$ \\
\hline Gas hard coal & 35 \\
\hline Semifat hard coal & 26 \\
\hline Carbonite hard coal & 18 \\
\hline Anthracite week hard coal & 12 \\
\hline Anthracite & 4 \\
\hline
\end{tabular}

The hard coal in the Jiu Valley can be classified in two groups: flaming hard coal, exploited in the eastern side of the coal basin, and gas hard coal, exploited in the western side of the coal basin. It must be understood that the passage from one type of hard coal to another is not sudden but in stages, the characteristics of the coal varying from eastern to 
western part between the limits shown in the above table. Agglutination characteristics. The agglutination power is determined in the laboratory by the free swelling in a caster of the coal that was finely grounded and rapidly heated to 820 degrees Celsius. The resulting profiles are compared to the ones stated in STAS 5266-69. Another method of determining the agglutination power is to use the Roga indicator, determined by the rapid heating of the powder and determining the mechanical resistance of the resulting carbonite. Brown coal does not have this characteristic and it stays powdery after heating. By agglutination, the hard coal in the Jiu Valley form a button with a differing swelling degree, depending on the eastern or western area of the coal basin. Coal humidity is given by the coal structure and by the local conditions of the coal deposit. Moisture content (Wi) represents the water quantity that is lost by the coal by air drying, until it reaches a constant weight; it comes from the coal deposit humidity or from the washing water from coal preparation. Hygroscopic moisture (Wh) represents that quantity of water that is left in the coal after the elimination of humidity content by oven-drying at 105 degrees Celsius or by boiling with an appropriate solvent (xylene or gasoline). Hygroscopic moisture is lower than moisture content and, generally, it becomes higer for the younger coal $(15-25 \%$ for peat coal and lignite, compared to $0.5-2 \%$ for anthracite).

\subsection{Macroscopic and microscopic components of the humic coals}

From a mineralogical-petrographic point of view, coals are made up of both macroscopic components (lithotype) and microscopic components (macerals and microlithotypes). The mineralogical-petrographic are determined only by specialists by using macroscopic visual analysis and microscopic analysis on shined surfaces and thin sections. Due to the language that is characteristic of geology and difficult to understand by specialists from other fields, we will succinctly describe this process, after a short presentation of the specific terminology. The components that can be macroscopically distinguished in the coal 's mass are called lithotypes and they correspond to some typical associations of structural, microscopical elements, named maceral constituents. The macerals and maceral groups, named analogically to the rocks' minerals, represent the last optically identifiable entities in the mass of humic coals. The composition and the characteristics of the maceral groups and of the macerals change with the degree of carbonization of the coal and they are mainly identified based on morphological characteristics. The physical-structural parameters that lead to the identification of the degree of carbonization of the coal refer, first of all, to reflectance, bireflectance, transparence, fluorescence, and, secondly, to density, hardness, optical anisotropy and behavior at $\mathrm{X}$ radiation.

\subsubsection{Macroscopic components of humic coals}

The macroscopic study of coals aims to determine the following physical properties: color, scratch mark, gloss, crack, cleavage, radioactivity, structure and texture. The macroscopic study of coals is therefore very important, because the determination of the lithotypes (petrographic components) allows some correlations from one stratum to another, or from a mine field to another. An easy feature to determine is the trace left by the coal on the porcelain plate: brown in the case of brown coal and black in the case of hard coal. Macroscopically speaking, in what regards inferior humic coals (lignite and earthy brown coal) more lithotypes were seen than in the case of superior humic coals (hard coals and anthracites). More recent nomenclatures distinguish the following lithotypes, characteristic to inferior humic coals: xylaine, xylitic coal, detritic coal, gelitic coal, fusitic coal and fusain. In the case of macroscopic study of the inferior humic coals, besides the above mentioned lithotypes, we can distinguish stripes made of coal and mineral substances that 
can sometimes reach up to $50 \%$ of the coal mass. These stripes are made of argillitic minerals, quartz powders, carbonates (especially calcium carbonates), sulphides (pyrite and sometimes, marcasite), sulphates (predominantly gypsum), rock salt etc. These mineral components are more frequent in the case of detritic coal. Macroscopically speaking, in the case of superior humic coals (hard coals and anthracites), less lithotypes were highlighted, but better individualized. They can be easily recognized due to their color, gloss and marked stratification. Thus, we can distinguish the following lithotypes: glossy coal (vitrain), semi glossy coal (clarain), dull coal (durain) and fibrous coal (fusain). Often, these macerals give the coal a striped look (in bands). In the hard coal category, each lithotype is usually made up of a predominant maceral. Thus, in the case of glossy coal, the highest ratio belongs to vitrinite, in the case of semi glossy coal exinite predominates and in the case of fibrous coal, we most often find inertinite.

\subsubsection{Microscopical components of humic coals}

Microscopical components of inferior humic coals (peat coals, lignite and brown coals) are made up of macerals and microlithotypes. Macerals, the correspondents of minerals from inorganic rocks, are microscopic constituents of coals (combustible organogenic rocks), made up of parts of different organs or tissues of the plants that have suffered some modifications during the carbonization process. The physical, chemical and technological properties of a coal depend on the proportion and the type of association of these components. Both in polished sections (slabs) and thin sections, macerals can be optically distinguished by their morphological appearance, by color, power of reflection, anisotropy and sometimes by fluorescence. They are also different by some physical properties (density, Wickers microhardness, fragility), as well as by their elementary composition, calorific power etc. In what regards inferior humic coals and especially lignite, we can see three maceral groups: the huminite group (with the subgroup of humotelinite which, in its turn, is subdivided in textinite and ulminite macerals, and with the subgroup of humodetrinite, in which, according to the gelling degree, we can see the macerals attrinite and densinite and with the subgroup of humocolinite, which comprises the macerals gelinite and corpohuminite. The liptinite group, also known as exinite can be seen in the componence of inferior humic coals (and is named liptinite) and in the componence of superior humic coals (and is named exinite). The liptinite group (more exactly exinite) is made up of the following macerals: resinite, cutinite, sporinite, suberinite, chlorophyllinite, alginite, lipodentrinite, bituminite, fluorinite and exudatinite. The inertinite group, just as the liptinite group and the macerals in this group appear in the componence of both, inferior humic coals and superior humic coals. The way the macerals in the two coal categories are classified is almost identical: semifusinite, fusinite, sclerotinite, macrite, micrinite and inertodetrinite. In the componence of superior humic coals the following three maceral groups can be seen: vitrinite, exinite and inertinite. As the exinite and inertinite maceral groups were described in the section dedicated to inferior humic coals, we will discuss the vitrinite group in the following. This group is made up of macerals: telinite (with the maceral varieties of lepidophytotelinite and sigillarotelinite), colinite (telocolinite, desmocolinite and corpocolinite) and vitrodetrinite. The associations of components of humic coals were named "microlithotypes". In both inferior humic coals and superior humic coals we have identified monomaceral microlithotypes, bimaceral microlithotypes and trimaceral microlithotypes. But in the case of superior humic coals, the most numerous are the monomacerals and the bimacerals. As all these aspects are too detailed to be discussed, in the following we will detail a few of the petrographic differences between the inferior and superior humic coals. 


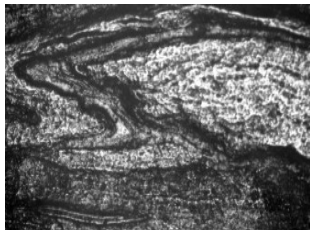

a) Textinite

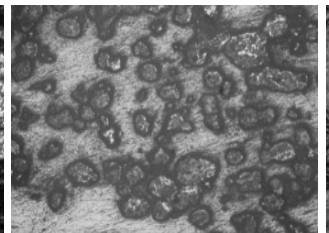

b) Corpohuminite

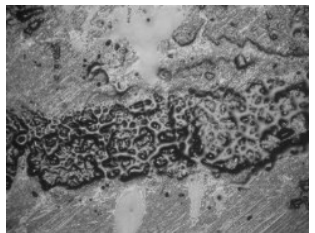

c) Resinite

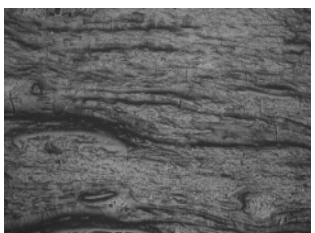

d) Cutinite

Fig. 2. Microscopical images that indicate the different macerals in inferior and superior humic coals $(\mathrm{x} 100)$

\subsubsection{The petrographic composition and the microstructure of humic coals with a different carbonization degree}

Inferior humic coals have a composition that is different from that of superior coals, due to the different vegetal material that generated them and due to their reduced stage of evolution. In the case of inferior coals, the predomination of huminitic macerals in comparison to the vitrinitic ones can be seen up to the stage of semi glossy coal and then their proportion decreases as the degree of carbonization advances. In the case of hard coal, from the three main maceral groups (vitrinite, exinite and inertinite), the first is the most important for the technological properties of the groups. The hard coal vitrinite has resulted after more intense carbonization processes of the huminite of brown coals. Each maceral subgroup of huminite, after the mentioned processes, has generated a type of vitrinitic maceral specific to hard coals.

\subsection{Mineral components of humic coals}

Alongside macerals and microlithotypes, we can also find mineral components in the composition of coals. They can be syngenetic, meaning they were deposited at the time of the formation of coals during the first stage of carbonization or can be of epigenetic (diagenetic) origin, deposited from the ascendant or descendant solutions that circulated along the fissures and cracks from the coal mass after the differentiation of macerals. The most frequent are argillitic minerals, represented by kaolinite, illite and montmorillonite. Sometimes, these are accompanied by sericite and chlorite. From the point of view of their origin, they are, for the most part, syngenetic, but illite and chlorite can also be epigenetic, as they result from the transformation of syngenetic minerals. The carbonates group consists of both syngenetic minerals (represented by concretions with different dimensions of siderite, ankerite, dolomite and calcite) and epigenetic minerals, placed on the trajectory of the fissures, cracks and in some cavities of the macerals (calcite, ankerite, dolomite etc.). Sulphurs occur more rarely, and are represented by syngenetic nests and concretions of pyrite, marcasite and melnicovite. In some coals, we also found concretions made up of pyrite, chalcopyrite and blende or pyrite, chalcopyrite and galena. Syngenetic pyrite has also been found under the form of very smooth crystals, singular or associated in rows usually oriented parallel to the coal schistosity. Epigenetic pyrite can also result from the transformation of the concretions of iron carbonate (siderite). Iron oxides and hydroxides are also rarely seen in coals, but they appear mostly in woody coals (xylite coals). They are represented by: hematite, limonite, goethite, diaspor and lepidocrocite and can be found especially along the fissures that affect some macerals, alongside argillitic minerals. Syngenetic phosphates, represented by apatite and phosphorite, can be seen very rarely in the componence of coal. Some mineral components, also called allogenic, come, in the 
majority of cases, from the surrounding environment. They are represented by powders of quartz, feldspars, fine tinsels of mice, argillitic minerals and heavy minerals (magnetite, zircon, rutile, tourmaline etc. The syngenetic and epigenetic minerals named above can be seen in variable proportions in the composition of inferior and superior humic coals. When these are found in greater quantities, they form the so-called carbominerites. Carbominerites are associations between the coal substance and the mineral substance and are represented by: carbagilite, carbopyrite, carbankerite, carbosilicite and carbopoliminerite.

\section{Case study - identifying the origin of coals from energy mixtures sold on the market}

In order to exemplify the proposed method, we tested two samples of energy mixtures that can be found on the market. During the determination of the characteristics of the coal from samples 1 and 2, we realized that they are very inhomogeneous, and are constituted by coal mixtures. Because of this, we tested each piece of coal in the case of the larger ones. In what regards the coal detritus, we considered it to be made up of the types of coal identified in the case of the larger pieces, and the ratio of each type of coal was determined by algebraic methods, starting from the content of volatile matter specific to each type. Since the samples were dry when they were received, their hygroscopic humidity was reconstructed by keeping them in water for 24 hours, after which they were dried until they achieved constant mass. The value of the determined humidity was named reconstructed humidity. After undertaking all these tests, we reached the following conclusion:

Table 2. Sample 1

\begin{tabular}{|l|c|l|c|c|c|}
\hline \multirow{2}{*}{ Type of identified coal } & $\mathbf{W}$ & $\mathbf{W}$ reconstructed & $\mathbf{A}_{\mathbf{a n h}}$ & $\mathbf{V}_{\mathbf{m c}}$ & Quantity \\
\cline { 2 - 6 } & $\mathbf{\%}$ & $\mathbf{\%}$ & $\mathbf{\%}$ & $\mathbf{\%}$ & $\mathbf{g}$ \\
\hline brown coal 1 & 1,45 & 9,19 & 19,78 & 53,71 & 104 \\
\hline hard coal & 0,31 & & 32,82 & 45,54 & 282 \\
\hline small class & 1,35 & & 40,82 & 53,78 & 105 \\
\hline brown coal 2 & 0,22 & & 79,80 & 75,64 & 234 \\
\hline
\end{tabular}

The small class is made up of brown coal. In its entirety, the sample was constituted from approximately $40 \%(38,9 \%)$ hard coal and approximately $60 \%(61,1 \%)$ brown coal.

Table 3. Sample 2

\begin{tabular}{|l|c|c|c|c|c|}
\hline \multirow{2}{*}{ Type of identified coal } & $\mathbf{W}$ & $\mathbf{W}$ reconstructed & $\mathbf{A}_{\text {anh }}$ & $\mathbf{V}_{\mathbf{m c}}$ & Quantity \\
\cline { 2 - 6 } & $\mathbf{\%}$ & $\mathbf{\%}$ & $\mathbf{\%}$ & $\mathbf{\%}$ & $\mathbf{g}$ \\
\hline brown coal 2 & 0,88 & 0,69 & 55,84 & 52,53 & \multirow{2}{*}{127} \\
\hline brown coal 2 & & & 79,63 & 68,94 & \\
\hline small class & 0,64 & & 40,14 & 47,07 & 430 \\
\hline hard coal from the west & & & 10,08 & 38,62 & \multirow{2}{*}{121} \\
\hline hard coal from the west & & & 7,97 & 39,56 & \\
\hline hard coal of uncertain origin & & & 39,57 & 41,08 & 154 \\
\hline
\end{tabular}


The small class is made up of $40 \%$ hard coal and $60 \%$ brown coal. In its entirety, the sample was constituted from approximately 55\% (53,8\% hard coal and approximately $45 \%$ (46.2\%) brown coal.

\section{Conclusions}

The proposed method is based on selecting characteristics of the coal that are significantly different and on the basis of determining these parameters for mixtures and separately for the reference samples, by using algebraic methods we can determine the composition of the mixture. From a mineralogical-petrographic point of view, the challenge is to identify macroscopic components (lithotypes) and microscopic components (macerals and microlithotypes). Once they are determined, the proportions of these constituents, as well as the identification of the mineralogical constituents can lead to a certain diagnosis in what regards the type and the origin of the coals.

The proposed method is useful especially in the situations in which coal mixtures are made up by detritus (small class) and it is not possible to separate the coal grains according to mineralogical characteristics.

In addition to the characteristics of the coal considered, in certain situations the chemical composition of the ashes, transposed by the color of ash (for example the hard coal in the Pregheda basin is white, which is different from all other coals) may be relevant.

\section{References}

1. Buia G., Lorinţ C., (2010), Hard Coal Deposits in Romania/Depozite de huilă din România, Revista Minelor, vol. 16, Nr. 3, pp. 9-14;

2. Buia G., Lorinţ C., Nimară C., Lupuleac R., (2014), Role of Jiu Valley Hard Coal Deposits Between Eastern and Western European Energetic Constraints, Annals of the University of Petroșani, Mining Engineering, Vol. XV (XXXXII), Universitas Publishing House, Petroșani, Romania, pp. 21-28;

3. Lorinţ C., Buia G., Lupuleac R., (2013), Aspects on Economic Potential of Jiu Valley Coals, Annals of the Unyversity of Petroşani, Mining Engineering, Vol. 14 (XXXXI), Petroşani, Romania, pp.81-88;

4. Petrescu I., Biţoianu C., Nicorici M., Mărgarit Gh., Nicorici E., Pătruţoiu I., Totdros C., Popescu D., (1986), Geologia zăcămintelor de cărbuni (vol. I), Probleme fundamentale, Ed. Tehnică, Bucureşti;

5. Petrescu I., Nicorici E., Biţoianu C., Ţicleanu N., Trodos C., Ionescu M., Mărgarit Gh., Nicorici M., Duşa A., Pătruţoiu I., Munteanu A., Buda, Geologia zăcămintelor de cărbuni (vol. II) Zăcăminte din România, (1987), Ed. Tehnică, Bucureşti;

6. Preda I., Bădăluţă A., Turculeţ I., Barus T., Androhovici A., Geologia zăcămintelor de cărbuni (Partea a II-a) - Răspândirea zăcămintelor de cărbuni, (1994), Ed. Universităţii din Bucureşti;

7. https://www.realitatea.net/furturile-de-carbune-din-valea-jiului-s-au-inmultitsimtitor 690137.html

8. https://zhd.ro/eveniment/vagoane-pradate-de-hotii-de-carbune-noua-oameni-au-fost-retinuti-depolitie/

9. https://www.reuters.com/article/idUS266722653020130901

10. https://cronicavj.ro/wp/?p=90376 